\title{
SISTEM INFORMASI KEAMANAN DATA ORGANISASI KAMMI KOMISARIAT SEBIDUK SEMARE KOTA LUBUKLINGGAU BERBASIS WEB MENGGUNAKAN METODE VIGENERE CHIPPER
}

\author{
Joni Karman ${ }^{1}$, Jamaludin M Akbar ${ }^{2}$ \\ Sistem Informasi Universitas Bina Insan ${ }^{1}$, Teknik Informatika Universitas Bina Insan ${ }^{2}$ \\ Email: jonikarman.mkom@gmail.com ${ }^{1}$, jamaludinmuhamadakbar96@gmail.com²
}

\begin{abstract}
ABSTRAK
Pembangunan sistem informasi pada Organisasi KAMMI Komisariat Sebiduk Semare Kota Lubuklinggau membahas teknik enkripsi dan dekripsi pada algoritma vigenere cipher berdasarkan tabel ACII menggunakan bahasa pemrograman PHP dan Web, untuk mempermudah admin KAMMI dalam memberikan informasi data-data seperti data agenda, data pelatihan, data perekrutan, dan data anggota. Penelitian ini menggunakan metode pengumpulan data, dengan cara melakukan pengamatan dan pencatatan langsung dari tempat penelitian (observasi), melakukan pengamatan dan tanya jawab langsung pada sumber. Hasil penelitian menunjukan bahwa aplikasi mengenai sistem informasi Keamanan Data Komisariat Sebiduk Semare Kota Lubuklinggau berbasis web menggunakan bahasa pemrograman PHP dan MySQL serta sublime text sebagai media penulisan listing program dan menggunakan metode Kriptografi yaitu Vigerenere Chipper. Dapat disimpulkan bahwa dengan perkembangan sistem informasi keamanan data pada Organisasi KAMMI Komisariat Sebiduk Semare Kota Lubuklinggau berbasis web dapat mempercepat proses deskripsi dan enkripsi pada database.
\end{abstract}

Kata Kunci: Sistem Informasi, Keamanan, Vigenere Chipper.

\section{ABSTRACT}

Development of information systems at the KAMMI Organization Lubuklinggau City Semare Commissariat discussing encryption and decryption techniques in vigenere cipher algorithms based on ACII tables using PHP and Web programming languages, to facilitate the KAMMI admin in providing information on data such as agenda data, training data, recruitment data, and member data. This study uses data collection methods, by making observations and recording directly from the place of research (observation), making observations and question and answer directly to the source. The results showed that the web-based application of information systems Security of Semuk City Semare Commissariat as of Lubuklinggau using PHP and MySQL programming languages and sublime text as media for writing program listings and using the Cryptographic method, Vigerenere Chipper. It can be concluded that with the development of data security information systems at the KAMMI Organization Webbased Semare City Semare Commissariat can speed up the process of description and encryption on the database.

Keywords: Information System, Security, Vigenere Chipper.

\section{Pendahuluan}

Kemajuan teknologi komputer membantu semua aspek kehidupan manusia, dari hal yang kecil sampai keberbagai hal yang sangat rumit sekalipun bisa dikerjakan oleh teknologi komputer. 
Contoh dari kemajuan teknologi komputer yang paling nyata dapat digunakan oleh semua orang adalah kecepatan dalam menyampaikan pesan dari tempat yang jauh. Salah satu perkembangan yang paling pesat saat ini adalah perkembangan teknologi mobile atau telepon seluler. Telepon seluler sebagai salah satu maha karya anak manusia dalam bidang komunikasi, memang tidak dapat terlepas dari kehidupan masyarakat modern seperti sekarang. Dengan harga murah dan fungsinya yang sangat penting, maka tidak mengherankan telepon seluler menjadi primadona dalam masyarakat baik itu masyarakat kelas atas hingga bawah. Telepon seluler atau yang sering kita sebut dengan handphone mampu berkomunikasi dengan content yang tidak terbatas pada suara, melainkan gambar, film, atau sembarang data digital dapat dilewatkan melalui jalur komunikasi seluler. Lebih jauh teknologi seluler memungkinkan handphone untuk berkomunikasi dengan internet dalam memberikan informasi yang cepat dan efisien.

Pembahasan tentang keamanan komputer sangatlah luas dan tidak habishabisnya. Dalan hal ini penulis akan membahas peran utama kriptografi dalam mengamankan data pada sistem jaringan komputer, baik diluar maupun yang didalam (intranet). Kriptografi berfungsi sebagai benteng utama untuk mengamankan data itu sendiri.

Masalah keamanan data Komputer dan kerahasian data merupakan suatu sangatlah penting dalam era informasi ini. Keamanan data pada komputer tidak hanya bergantung pada firewall dan intrusion detection system saja, keamanan data dari data itu sendiri sendiri merupakan hal yang sangat perlu diperhatikan, jika firewall dan perangkat keamanan lainnya bisa dibobol oleh orang yang tidak berhak maka, peran utama kriptografi untuk mengamankan data dan dokumen dengan menggunakan teknik enkripsi, sehingga data dan document tidak bisa dibaca. Di mancanegara perkembangan Kriptografi sangat pesat, hal ini merupakan suatu tanda bahwa informasi merupakan elemen yang sangat penting yang perlu diamankan.

kriptografi adalah ilmu dan seni untuk menjaga keamanan pesan ketika pesan dikirim dari suatu tempat ke tempat yang lain. Untuk berbagai alasan, keamanan dan kerahasiaan sangat kita butuhkan dalam komunikasi data. Ada berbagai cara untuk menjamin keamanan dan kerahasiaan komunikasi data kita di antaranya adalah dengan seni pengacakan data atau disebut juga Kriptografi.

KAMMI (Kesatuan Aksi Mahasiswa Muslim Indonesia) lahir pada 29 Maret 1998 di Malang dan menjadi salah penggerak aksi reformasi 1998. KAMMI pada perkembangannya mentransformasikan diri dari gerakan mahasiswa muslim yang berbasis literasi, diskusi, dan aksi sosial.

Sistem informasi keamanan data pada anggota KAMMI berbasis web merupakan sistem khusus yang digunakan untuk keperluan keamanan data pada anggota KAMMI kota Lubuklinggau dengan menggunakan metode Vigenere Chipper. Penelitian ini akan mengimplemtasikan tentang bagaimana merancang pengolahan data dan keamanan data anggota KAMMI kota Lubuklinggau yang dituangkan dalam bentuk penelitian dengan judul "Sistem Informasi Keamanan Data Organisasi KAMMI Komisariat Sebiduk Semare Kota Lubuklinggau Berbasis Web Menggunakan Metode Vigenere Chipper

\section{Landasan Teori}

\subsection{Sistem}

Sistem Informasi adalah suatu sistem didalam suatu organisasi yang mempertemukan kebutuhan pengolahan transaksi harian yang mendukung fungsi operasi organisasi yang bersifat manajerial dengan kegiatan strategi dari suatu organisasi untuk dapat menyediakan kepada pihakluar tertentu dengan laporan-laporan yang diperlukan. 


\subsection{Informasi}

Informasi adalah data yang telah diklasifikasikan atau diolah atau diinterprestasikan untuk digunakan dalam proses pengambilan keputusan.

Informasi adalah hasil pengolahan data dari satu atau berbagai sumber yang kemudian diolah, sehingga memberikan nilai, arti dan manfaat.

\subsection{Keamanan Data}

Keamanan data menjadi hal yang sangat penting pada saat ini karena untuk setiap pengambilan keputusan, kebijakan harus berdasarkan data.Banyak data yang berisikan informasi penting dan terbatas untuk diketahui pihak yang terkait saja.Faktor keamanan data menjadi sangat penting dan harus diperhatikan. Salah satu cara untuk meningkatkan keamanan data diperlukan kriptografi dengan metode enkripsi.

\subsection{Kriptografi}

Kriptografi adalah ilmu dan seni untuk menjaga kerahasiaan berita. Selain pengertian tersebut terdapat pula pengertian ilmu yang mengajari teknik-teknik matematika yang berhubungan dengan aspek keamanan informasi seperti kerahasiaan data, keabsahan data, integritas data, serta autentifikasi data.

Kriptografi memiliki 4 komponen utama yaitu :

1) Plaintext, yaitu pesan yang dapat dibaca

2) Ciphertext, yaitu pesan sandi / pesan acak yang tidak bisa dibaca

3) Key, yaitu kunci untuk melakukan teknik kriptografi

4) Algoritma, yaitu metode untuk melakukan enkripsi dan deskripsi

\subsection{Algoritma Vigenere Chipper}

Vigenere Chipper adalah salah satu algoritma kriptografi klasik yang diperkenalkan pada abad 16 atau kira-kira pada tahun 1586. Algoritma kriptografi ini dipublikasikan oleh seorang diplomat dan juga kriptologis yang berasal dari Perancis, yaitu Blaise de Vigenere, namun sebenarnya algoritma ini telah digambarkan sebelumnya pada buku La Cifra del Sig. Giovan Belase, pada tahun 1553.

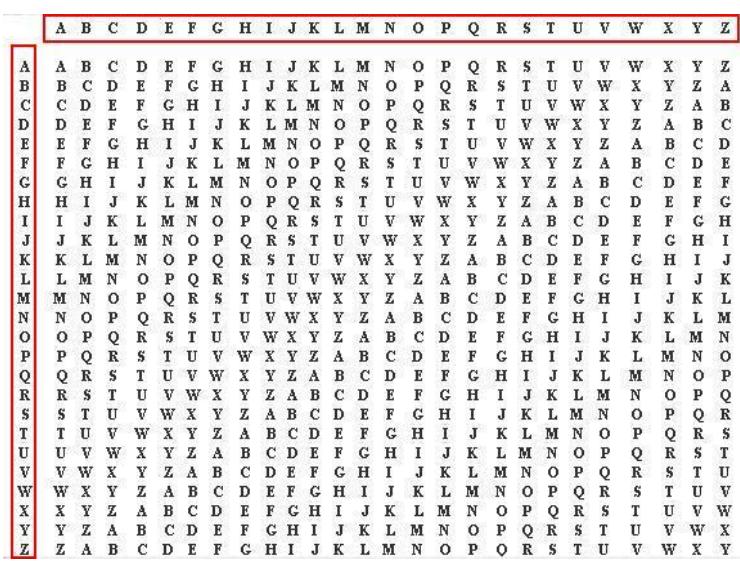

Gambar 1. Tabel Pemetaan Vigenere Chipper

\subsection{PHP}

PHP merupakan bahasa pemrograman yang ditujukan untuk membuat aplikasi web. Ditinjau dari pemrosesannya, PHP tergolong berbasis server side. Artinya pemrosesan dilakukan di server. Hal ini berkebalikan dengan bahasa seperti JavaScipt, yang pemrosesannya dilakukan disisi klien (client side). PHP sering dikatakan sebagai bahasa untuk membuat aplikasi web yang dinamis. Pengertian dinamis ini disini adalah memungkinkan untuk menampilkan data yang tersimpan dalam database. Dengan demekian, halaman web akan menyesuaikan dengan isi database.

\section{7. $M y S q l$}

MySQL adalah nama database server. Database server adalah server yang berfungsi untuk menangani database. Database adalah suatu pengoraganisasian data dengan tujuan memudahkan penyimpanan dan pengaksesan data. Dengan menggunaka MySQL, kita bisa menyimpan data yang kemudian data bisa diakses dengan mudah dan cepat. MySQL tergolong sebagai database relasional. Pada model ini, data dinyatakan dalam bentuk 
dua dimensi yang secara khusus dinamakan tabel. Tabel tersusun atas baris dan kolom.

\section{Hasil Dan Pembahasan}

Implementasi Sistem Informasi Keamanan Data Organisasi KAMMI Komisariat Sebiduk Semare Kota Lubuklinggau Berbasis Web menggunakan Metode Vigenere Chipper Merupakan tahapan akhiir dibuat, hasil juga dapat menentukan apakah sistem layak untuk diterapkan atau tidak, selain itu hasil penulis juga dapat melihat kekurangan kekurangan apa saja yang ada dalam sistem, sehingga waktu yang akan dapat diperbaiki.

\subsection{Rancangan Sistem}

Rancangan analisis penulis akan melakukan perancangan sistem Keamanan data menggunakan Vigenere chipper untuk mengetahui Data anggota dengan menggunakan diagram UML:

a. Use case

Use case diagram merupakan fungsionalitas yang diharapkan dari sebuah sistem yang ditekan adalah "apa" yang diperbuat sistem, dan bukan "bagaimanana". Sebuah use case mempresentasikan pada interaksi antar aktor dengan sistem, perancangan use case diagram nya dapat dilihat pada gambar 2 .

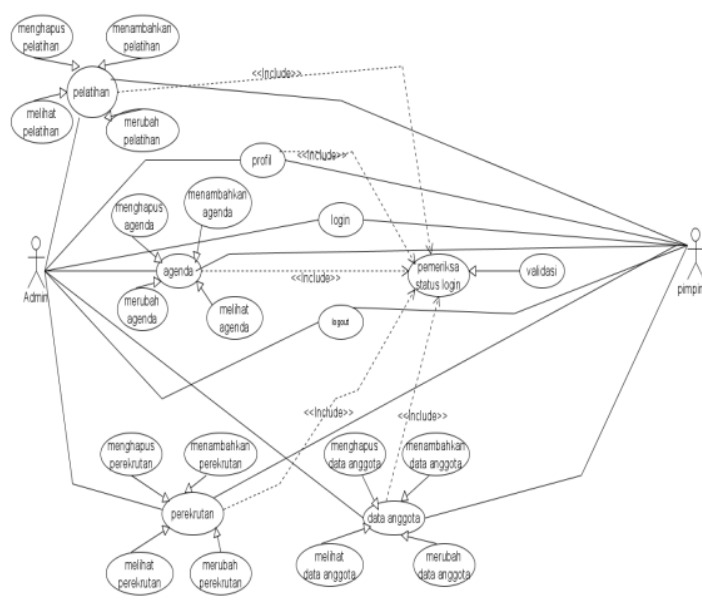

Gambar 2. Use case

Pada gambar 2. dapat defenisikan aktor yakni aktor terdiri dari admin dan pimpinan. Admin adalah orang yang bertugas dan memiliki hak akses untuk melakukan operasi pengolahan data anggota, data perekrutan, data agenda, data pelatihan dan profil. Sedangkan Pimpinan adalah orang yang hanya diperbolehkan melihat data anggota, perekrutan, agenda, pelatihan, dan profil.

Deskripsi berikutnya adalah deskripsi Use case yakni Login adalah proses untuk melakukan login admin dan pimpinan, Logout adalah proses untuk melakukan logout admin dan pimpinan. Kemudian Mengelola Pelatihan proses untuk pengelolaan data pelatihan yaitu memasukkan, mengubah, menghapus, dan melihat pelatihan. Mengelola Perekrutan proses untuk pengelolaan data Perekrutan yaitu memasukkan, mengubah, menghapus, dan melihat Perekrutan. Mengelola Agenda proses untuk pengelolaan data Agenda yaitu memasukkan, mengubah, menghapus, dan melihat Agenda. Mengelola Anggota proses untuk pengelolaan data Anggota yaitu memasukkan, mengubah, menghapus, dan melihat Anggota.

b. Class Diagram

Class Diagram menggambarkan struktur sistem dari segi pendefinisian kelas-kelas yang akan dibuat membangun fungsi-fungsi yang dimiliki oleh kelas. perancangan Class Diagrm diagram nya dapat dilihat pada gambar 3 .

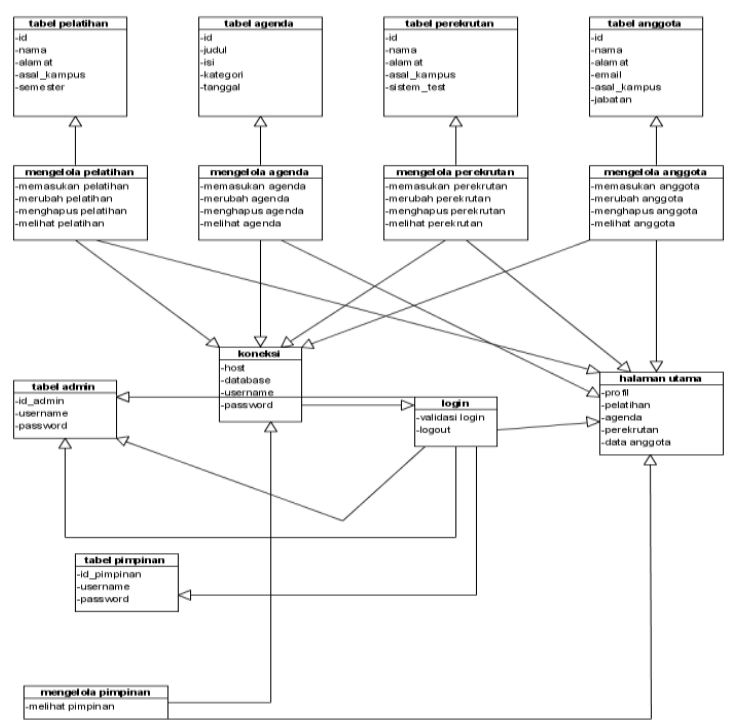

Gambar 3. Class Diagram 
Pada gambar 3. terdiri dari class name, relasi antar kelas, interface, yang nantinya dijadikan sebuah rancangan database pada sistem serta rancangan antarmuka desain sistem.

\subsection{Login}

Halaman Login admin merupakan halaman yang tampil pertama kali user membuka admin site program studi sistem informasi KAMMI, dan admin diwajibkan untuk login sebelum mengolah data.

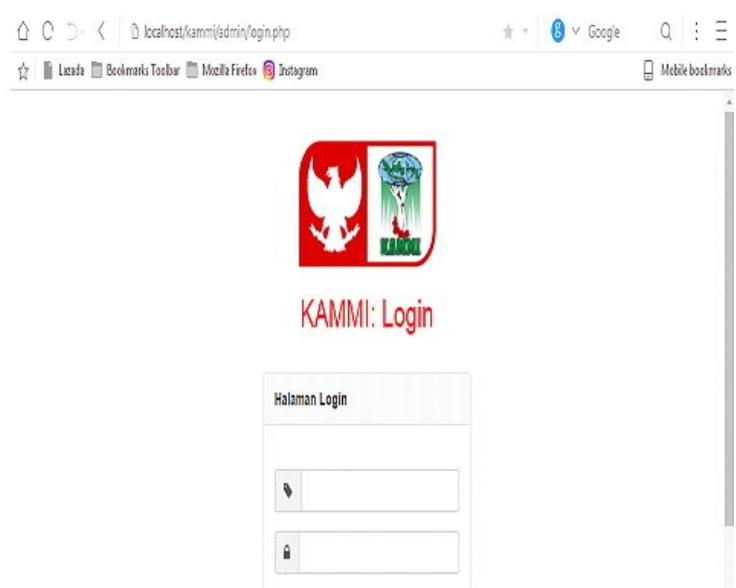

Gambar 4. Halaman Login

\subsection{Halaman Pelatihan}

Halaman pelatihan merupakan tampilan digunakan untuk melihat data pelatihan, pada halaman ini admin bisa menambah, mengubah data pelatihan.

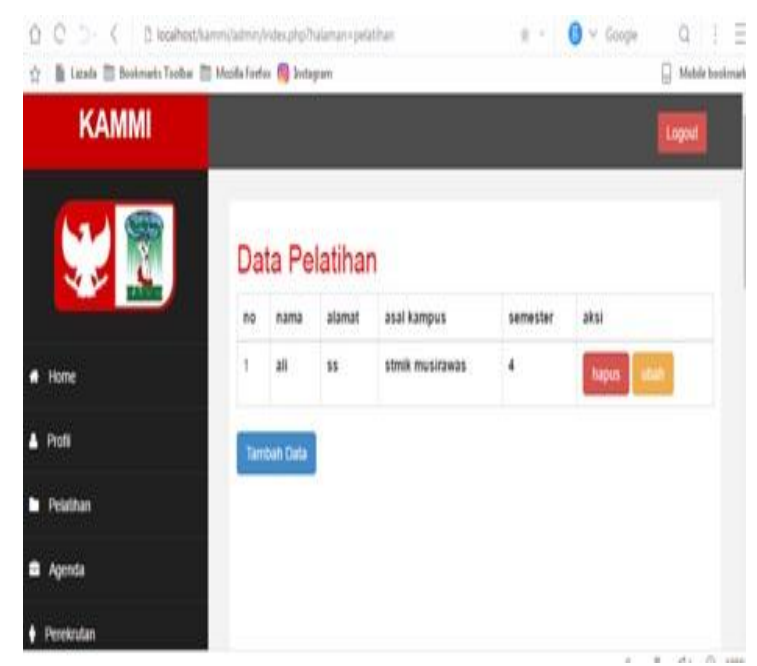

Gambar 5. Halaman Pelatihan

\subsection{Halaman Agenda}

Halaman agenda merupakan tampilan digunakan untuk melihat data agenda pada halaman ini admin bisa menambah, mengubah data Agenda.

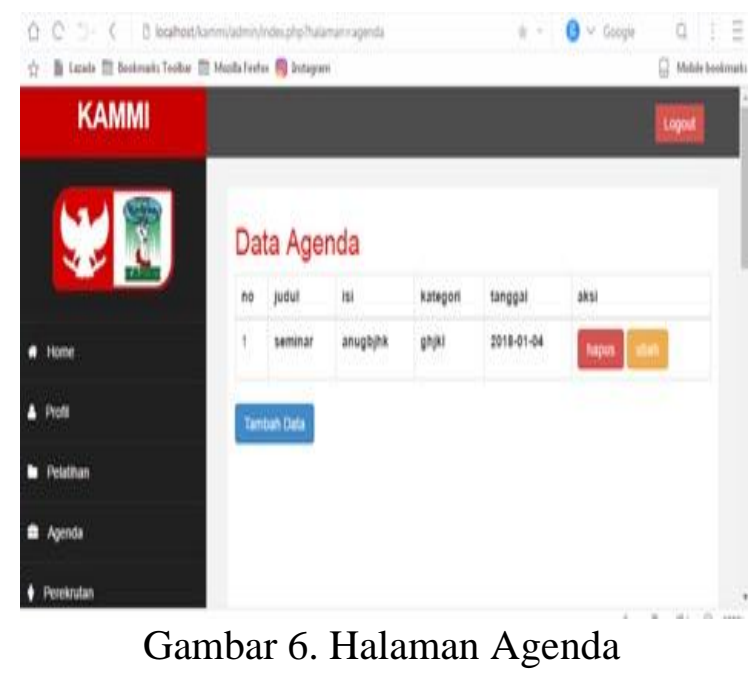

\subsection{Halaman Perekrutan}

Halaman perekrutan merupakan tampilan digunakan untuk melihat data perekrutan. pada halaman ini admin bisa menambah, mengubah data Perekrutan.

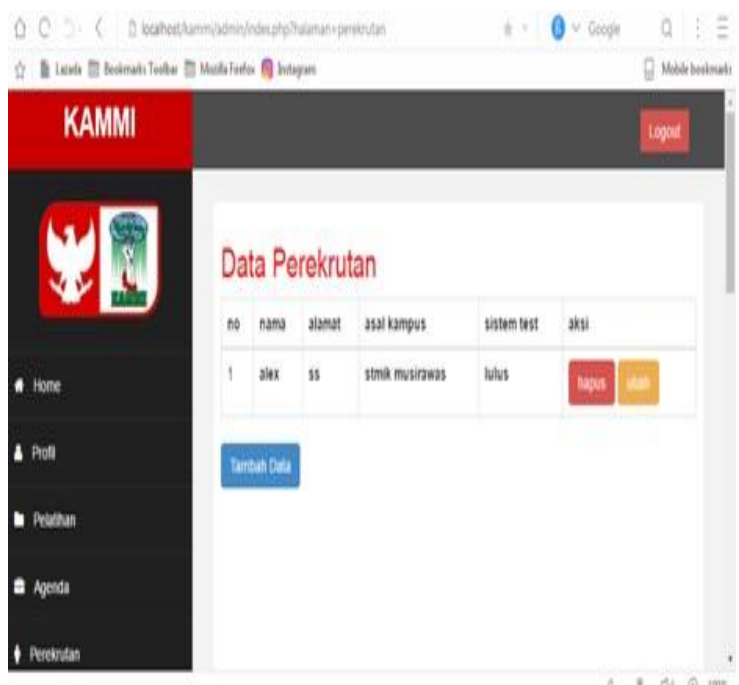

Gambar 7. Halaman Perekrutan

\subsection{Halaman Anggota}

Halaman anggota merupakan tampilan digunakan untuk melihat data anggota. halaman ini admin bisa menambah, mengubah data anggota. 


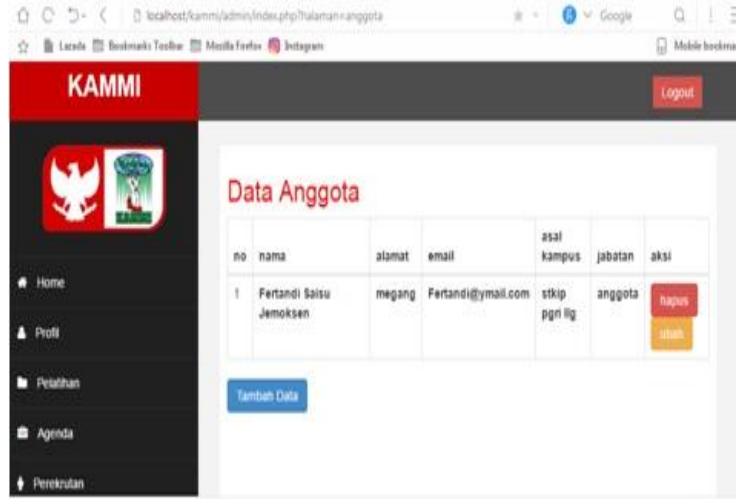

Gambar 8. Halaman Anggota

\subsection{F. Halaman Tabel Database Yang Ter-enkripsi}

Halaman tabel database yang terenkripsi terdiri dari empat tabel yang terenkripsi yakni tabel anggota, tabel agenda, tabel perekrutan, tabel pelatihan yang dapat dilihat pada gambar 9 sampai dengan gambar 12 .

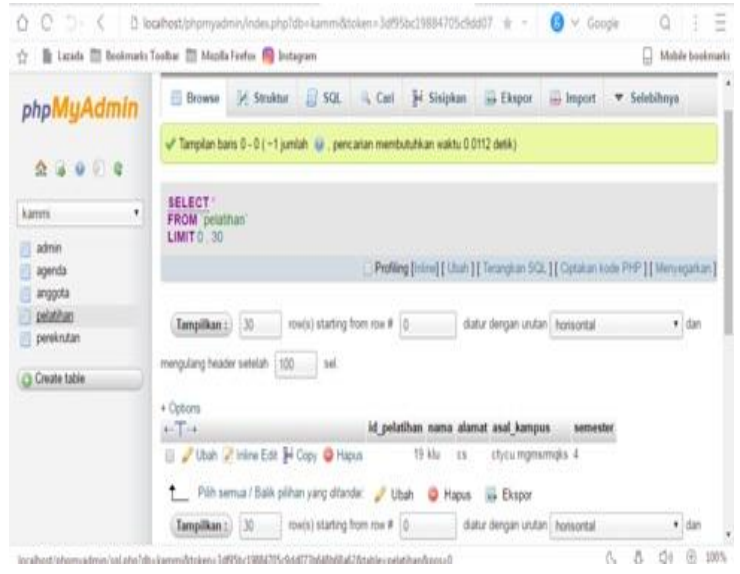

Gambar 9. Halaman Tabel Anggota

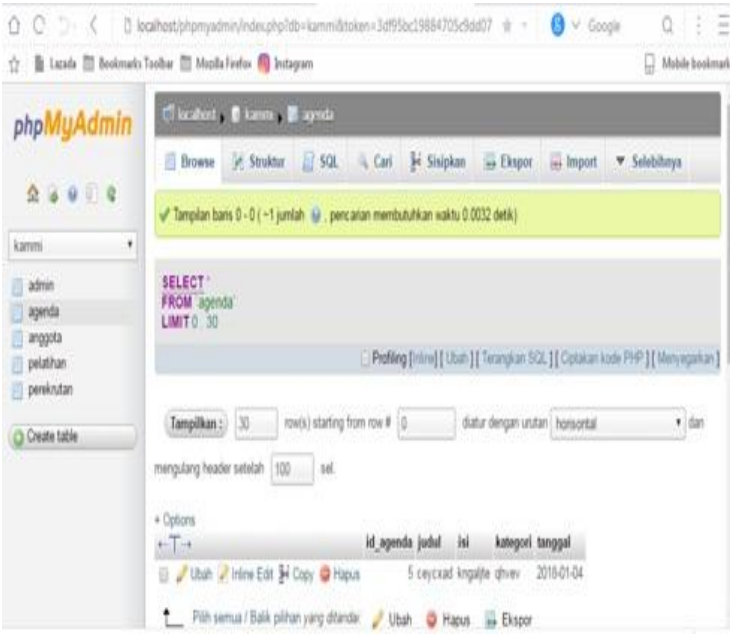

Gambar 10. Halaman Tabel Agenda

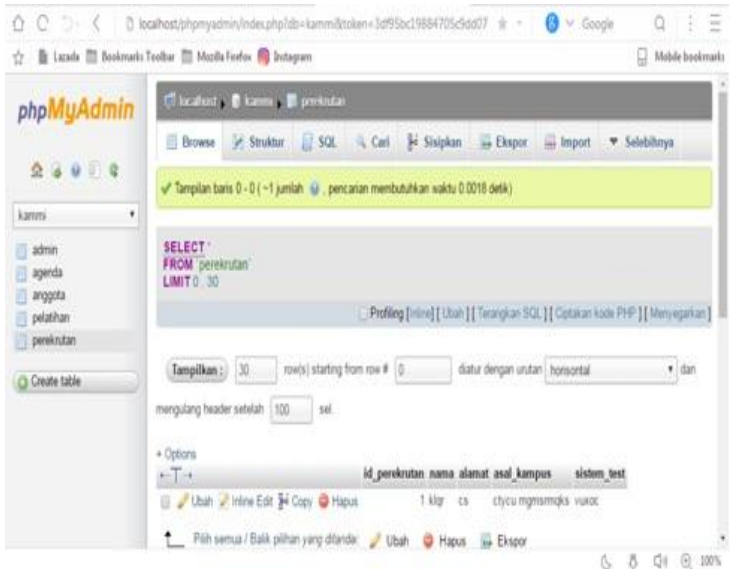

Gambar 11. Halaman Tabel Perekrutan

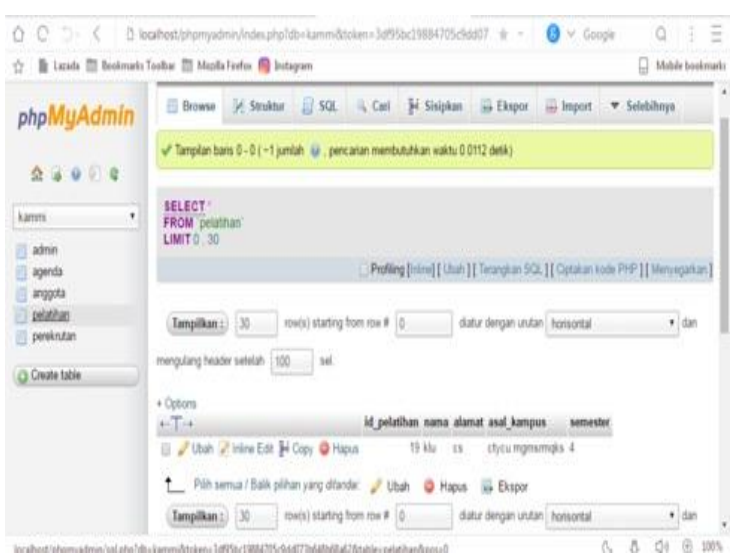

Gambar 12. Halaman Tabel Pelatihan

\section{Kesimpulan}

Setelah melakukan penelitian pada proses Sistem informasi Keamanan data pada Organisasi KAMMI, maka dihasilkan sebuah program. Dari hasil penelitian tersebut, maka dapat disimpulkan. terdapat beberapa permasalahan pada KAMMI Komisariat Sebiduk Semare Kota Lubuklinggau sistem informasi keamanan data masih menggunakan cara manual, keamanan data tersebut menggunakan metode vigenere chipper, vigenere chipper dapat dilakukan dengan mudah khususnya untuk vigenere standar, dengan mengubah pesan kunci ke dalam angka sebelum dilakukan proses enkripsi dan deskripsi. Proses enkripsi dan deskripsi dalam keamanan data tidak berbeda secara signifikan 


\section{Daftar Pustaka}

Abdul Kadir (2013). Pengertian MySQL.

Tersedia dalam : Buku Pintar

Programer Pemula PHP.

Yogyakarta. Mediakom

Abdul Kadir (2013). Pengertian PHP. Tersedia dalam : Buku Pintar Programer Pemula PHP. Yogyakarta. Mediakom

Apriandala, Rio, 2013, Sistem Keamanan Menggunakan Rubik Dengan Algoritma Kriptografi Encryption, Tugas Besar I Makalah Kriptografi, Universitas Bengkulu. $375 \mathrm{Hal}$

D. A. W. Pratiwi, "Peningkatan Keamanan Data Dengan Metode Cropping Selection Pseudorandom," vol. 4, p. 3, 2016

Edy Winarno, Ali Zaki, SmithDev. 2014. Pemrograman Web Berbasis HTML5, PHP, dan JavaScript. Jakarta: PT Elex Media Komputindo

Efrandi, et al, 2014, Aplikasi Kriptografi Pesan Menggunakan Algoritma Vigenere Cipher, Jurnal Media Infotama, Vol. 10, No.2, 120 128

Hidayat, Akik, 2009, Kriptografi Dan Stenografi Menggunakan Algoritma Vigenere Dan Tea ( Tiny Enkripsiion Algorithm), Repositoy UNPAD, Indonesia

Pratama, I Putu Agus, E 2014, Sistem Informasi dan

Implementasinya, INFORMATIKA, Bandung

Sutabri, Tata., Sistem Informasi manajemen, Yogyakarta: Andi Offset, 2005

Sutabri, T, 2012, Analisis Sistem Informasi, CV ANDI OFFSET, Yogyakarta. 